\title{
Plasminogen/plasmin influence on platelet aggregation
}

\author{
Y. M. Roka-Moya, D. D. Zhernossekov, T. V. Grinenko \\ Palladin Institute of Biochemistry, NAS of Ukraine \\ 9, Leontovicha Str., Kyiv, Ukraine, 01601 \\ chemikdd@mail.ru
}

\begin{abstract}
Aim. Determination of the influence of Glu- and Lys-plasminogen/ plasmin on the platelet aggregation induced by different agonists. Methods. Platelet aggregometry. Spectrophotometry. Results. We have shown the inhibitory effect of Lys-plasminogen on human platelet ag-gregation. The pro-enzyme action is related to the second wave of aggregation. The inhibitory effect of Lys-plasminogen possesses dose-dependent manner in case of thrombin-induced aggregation. The inhibitory effect of pro-enzyme with ristocetin as an inductor has not been observed. Glu-plasminogen and plasmin do not influence on platelet aggregation under studied conditions. A serine protease inhibitor aprotinin does not change the inhibitory effect of Lys-plasminogen. Conclusions. The results proved the inhibitory effect of Lys-plasminogen on thrombin- and collagen-induced platelet aggregation. The absence of inhibitory effect of Lys-plasminogen in the case of ristocetin-induced aggregation leads us to conclusion, that GP Ib/IX is not involved into the inhibited aggregation pathway. The unchanged inhibitory effect of Lys-plasminogen in the presence of aprotinin excludes plasmin partici- pation in the inhibitory phenomenon.
\end{abstract}

Keywords: platelet aggregation, plasminogen, plasmin.

Introduction. Plasminogen/plasmin system participates in many physiological and pathogenic processes, including fibrinolysis, inflammation and oncogenesis $[1,2]$. Plasminogen can interact with blood cells, and platelets demonstrate the highest ability of binding this protein [3].

Under normal conditions the membrane of platelets serves as a surface for the sorption of plasminogen and tissue plasminogen activator (TPA). There is an assumption that Glu-plasminogen, circulating in blood, binds to the platelet membrane and transforms into Lys- plasminogen with further formation of plasmin (Fig. 1) [4]. Therefore, the active enzyme can be relatively protected from its primary inhibitor alpha-2-antiplasmin, and the platelet surface acquires profibrinolytic properties. It was demonstrated that the affinity of platelets is three times higher for Lys-plasminogen compared to its Gluform, although the number of sites on the cell surface for Glu- and Lys-plasminogen is almost the same $\left(4.1 \cdot 10^{4}\right.$ and $5.5 \cdot 10^{4}$ sites per cell, respectively) [5]. The sorption of components of plasminogen/plasmin sys-

(C) Institute of Molecular Biology and Genetics, NAS of Ukraine, 2012 tem on the cell surface influences the functional properties of platelets, in particular, their aggregation. The authors of $[6,7]$ demonstrated that the introduction of plasmin $(1 \mathrm{CU} / \mathrm{ml})$ to the platelet suspension leads to the stimulation of aggregation. However, other authors proved a decrease in the aggregation [8-10] when platelets were incubated with plasmin of lower concentration or of the same concentration, but under conditions of prolonged incubation period (20 min and more).

We have established that, contrary to Glu-plasminogen, Lys-plasminogen inhibits ADP-induced aggregation in the preparations of platelet-rich plasma [11]. However, only the experiments with washed platelets may confirm this effect of the proenzyme. In addition, it is important to establish the mechanism explaining Lys-plasminogen influence on the platelet surface.

The present work was aimed to study the effect of components of plasminogen/plasmin system on the aggregation of washed platelets, stimulated by different agonists.

Materials and Methods. The platelet aggregation was studied using the preparations of washed platelets, 


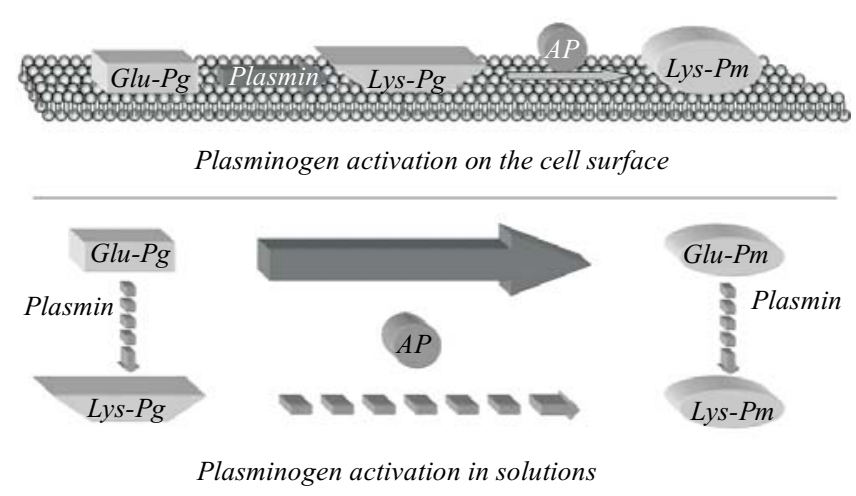

Fig. 1 The scheme of plasminogen activation (Pg)

obtained by the modified method [12]. Native washed platelets were isolated by stage-by-stage centrifugation of human blood, anticoagulated by the citrate buffer (100 mM sodium citrate, $80 \mathrm{mM}$ citric acid, $110 \mathrm{mM}$ glucose) in blood/anticoagulant ratio of 9/1.

Platelet-rich plasma (PRP) was obtained by blood centrifugation at $1000 \mathrm{rpm}$ for $20 \mathrm{~min}$ at room temperature. Then PRP was centrifuged again (1500 rpm, $20 \mathrm{~min})$, platelet precipitate was resuspended in washing buffer (20 mM HEPES, $\mathrm{pH} 6.8,137 \mathrm{mM}$ $\mathrm{NaCl}, 4 \mathrm{mM} \mathrm{KCl}, 0.2 \mathrm{mM} \mathrm{MgCl}$ with $0.2 \%$ glucose and $0.2 \%$ bovine serum albumin (BSA)). Cell suspension was centrifuged for the second time under the same conditions and resuspended in the buffer, the volume of which was $1 / 2$ of PRP volume. The washed platelets were kept at $37^{\circ} \mathrm{C}$.

Aggregometry was performed during the first three hours after blood sampling using optic aggregometer SOLAR AT-02 by the method, described in [13]. The platelet aggregation was stimulated by thrombin (1 $\mathrm{NIH} / \mathrm{ml})$, collagen $(1.25 \mathrm{mg} / \mathrm{ml})$ and ristomycin $(1.5$ $\mathrm{mg} / \mathrm{ml}$ ). The concentration of agonists was selected according to the recommendations of the work [14]. The aggregation process was registered for $5 \mathrm{~min}$. The number of platelets in the sample was 300-350 thousand $/ \mu 1$. Before the introduction of stimulator, the samples were incubated at $37{ }^{\circ} \mathrm{C}$ for 3 min to bind the components of plasminogen/plasmin system with the platelet surface [3].

The aggregometry data were analyzed using the Aggregometer 2.01 software package. The degree, time and rate of aggregation were estimated. The preparations of Glu-, Lys-plasminogen and plasmin were ob- tained by colleagues of Palladin Institute of Biochemistry according to [15]. The preparations of collagen, ristocetin and thrombin were purchased from Technology Standard (Russian Federation). Plasmin effect was inhibited with an inhibitor of serine proteinase, aprotinin - preparation "Contriven", Biopharma (Ukraine).

The amount of plasmin in Lys-plasminogen preparation and the possibility of its formation in the reaction mixture during the aggregation of platelets were determined by registering amidolytic activity of the enzyme with chromogenic substrate S2251 (SPA Renam, Russian Federation).

Results and Discussion. The experiments, performed on the washed platelets, revealed the inhibitory effect of Lys-plasminogen on the thrombin- and collagen-induced aggregation (Fig. 2 and 3). In both cases the level of aggregation decreases at least by two times. These data prove our previous investigations, which showed that Lys-plasminogen inhibits ADP-induced aggregation in PRP and the main effect of this proenzyme was observed during the second aggregation wave, when secretion of platelet alpha-granules occurs [11].

Similar effect we have observed with washed platelets during collagen-induced aggregation. The collagen effect on the platelets is known to be also related to the second aggregation wave.

Besides, we have studied Lys-plasminogen effect on ristocetin-induced aggregation, which is realized through the different mechanism. Ristocetin, binding with platelet membrane, triggers the association of von Willebrand factor with the receptor GP Ib/IX and the following platelet activation and agglutination. We have shown that Lys-plasminogen has not inhibited ristocetin-induced aggregation in the presence of autologous blood plasma as a source of von Willebrand factor (Fig. 4). Therefore, the absence of the proenzyme effect on ristocetin-induced aggregation indicated the specificity of Lys-plasminogen action .

We have established a dose-dependent manner of the inhibitory effect of Lys-plasminogen during the thrombin-induced aggregation. The most significant inhibitory effect of exogenous Lys-plasminogen was observed at the concentration of $1.2 \mu \mathrm{M}$ (Fig. 5). The further increase of proenzyme concentration did not enhance its inhibitory action. 


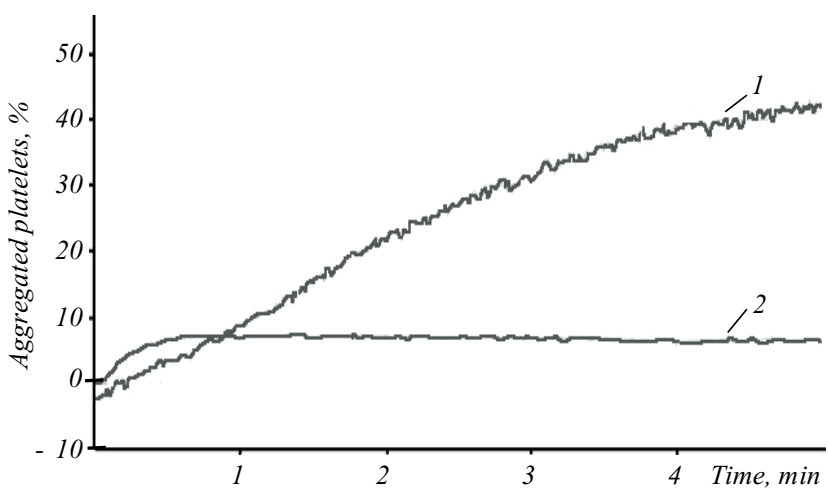

Fig. 2 The effect of Lys-plasminogen on platelet aggregation, induced by $1 \mathrm{NIH} / \mathrm{ml}$ of thrombin: 1 - control; $2-1.2 \mu \mathrm{M}$ Lys-plasminogen

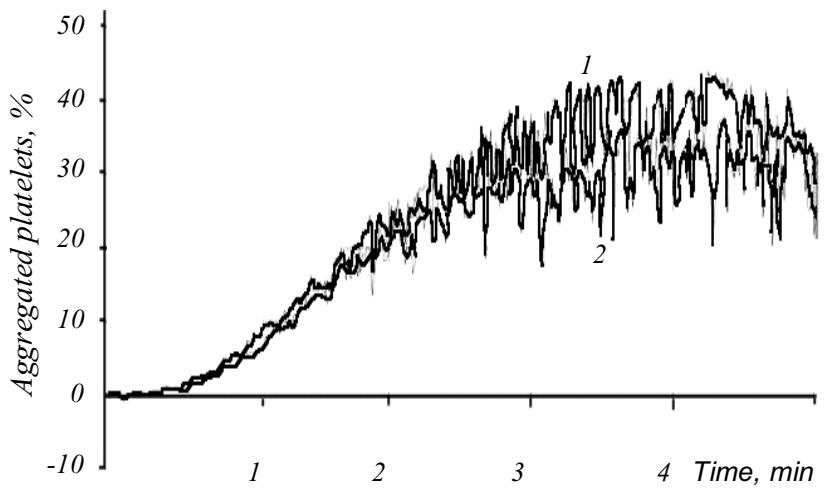

Fig. 4 The effect of Lys-plasminogen on platelet aggregation, induced by $1.5 \mathrm{mg} / \mathrm{ml}$ ristocetin: 1 - control; $2-1.2 \mu \mathrm{M}$ Lys-plasminogen

Since the preparations of Lys-plasminogen can possess spontaneous plasmin activity, we studied the effect of plasmin $(1 \mathrm{nM})$ on thrombin-induced platelet aggregation (the previous incubation with plasmin lasted 3 min). Plasmin concentration was selected according to its content in the preparation of Lys-plasminogen. The results of the experiment did not demonstrate any impact of plasmin on the thrombin-induced aggregation. This outcome is in a good agreement with the data of [16] which did not demonstrated any influence of nanomolar concentrations of plasmin on the thrombinstimulated aggregation, when the incubation time did not exceed $3 \mathrm{~min}$.

Our previous experiments with PRP established that Glu-plasminogen closed taken at the same concentrations as Lys-plasminogen made no influence on ADP-induced platelet aggregation. Our experiments with washed platelets confirmed the absence of Gluplasminogen influence on thrombin-induced platelet aggregation. The absence of the inhibitory effect could

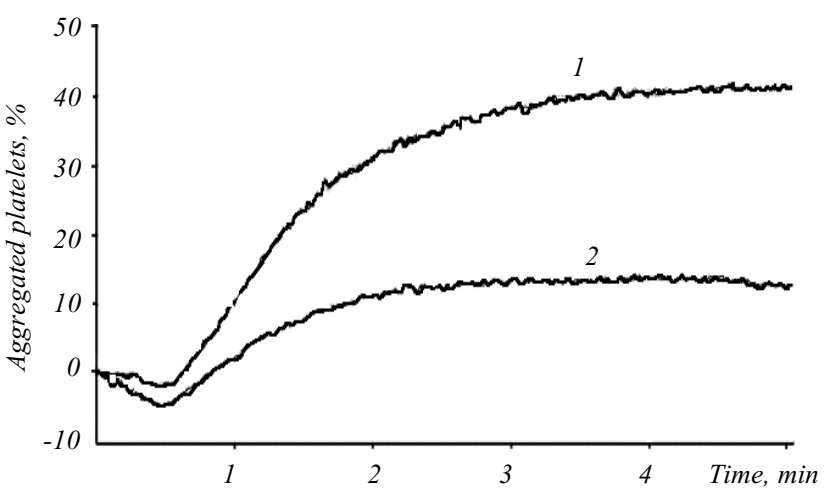

Fig. 3 The effect of Lys-plasminogen on platelet aggregation, induced by $1.25 \mathrm{mg} / \mathrm{ml}$ collagen: 1 - control; $2-1.2 \mu \mathrm{M}$ Lys-plasminogen

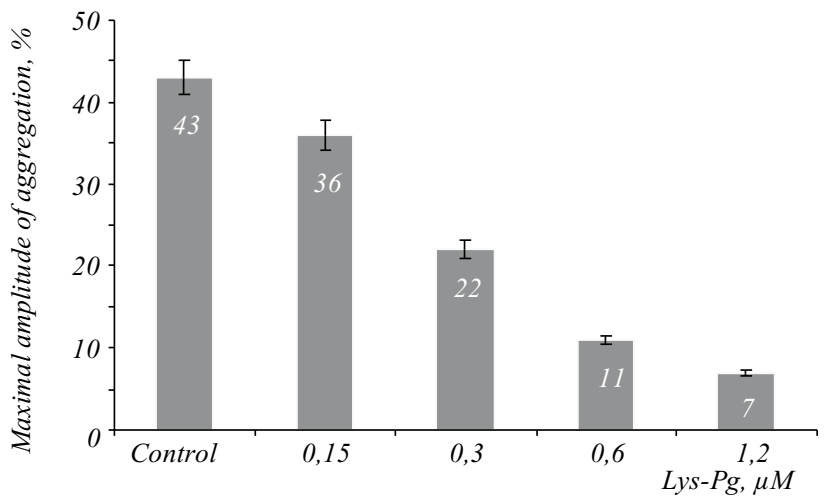

Fig. 5 The effect of Lys-plasminogen $(0.15-1.2 \mu \mathrm{M})$ on thrombin-induced platelet aggregation

be explained by the closed conformation of Glu-plasminogen.

It would be interesting to establish the mechanism of Lys-plasminogen activity. Probably, the observed effect is conditioned by the activity of plasmin, formed due to the activation of Lys-plasminogen on the platelet surface (as it was stated before, the spontaneous activity of plasmin in the preparation of Lys-plasminogen does not affect the thrombin-induced aggregation). If it is true, the inhibitory effect may be suppressed by the addition of the inhibitor of serine proteinases. To test this assumption, we have carried out a number of experiments with the inhibitor of serine proteinases, aprotinin. It was shown that aprotinin in the concentration of $5.5 \mathrm{IU} / \mathrm{ml}$ completely inhibits the plasmin proteolytic activity in both Lys-plasminogen preparation and incubation mixture. The introduction of aprotinin (5.5 $\mathrm{IU} / \mathrm{ml}$ ) to the reaction mixture does not influence the inhibitory effect of Lys-plasminogen on the thrombininduced aggregation of platelets (Fig. 6). It should be 


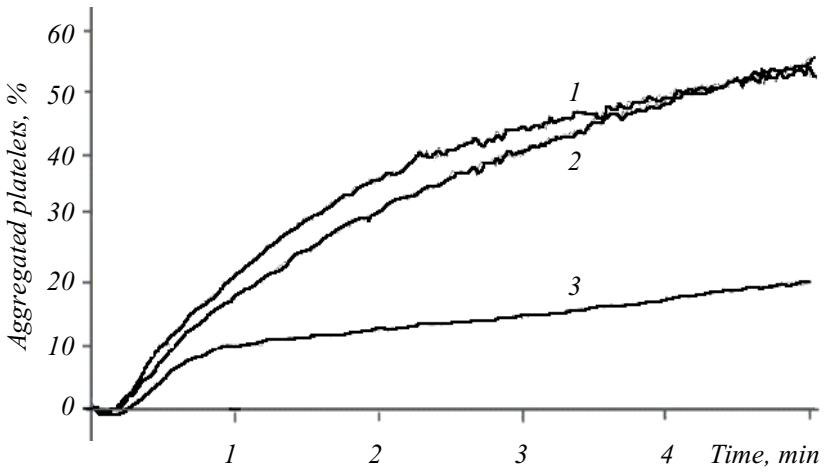

Fig. 6 The effect of aprotinin on the inhibition of thrombin-induced platelet aggregation by Lys-plasminogen: 1 - control; 2 - platelet aggregation in the presence of aprotinin (5.5 IU/ml); 3 Lys-plasminogen $(1.2 \mu \mathrm{M})$ in the presence of aprotinin

noted that this concentration of aprotinin does not inhibit the platelet aggregation. Therefore, the participation of plasmin in the realization of the inhibitory effect of Lys-plasminogen appears impossible.

On the other hand, Lys-plasminogen may bind some protein components - fibrinogen, thrombospondin and vitronectin, which are released during the secretion of alpha-granules and and condition aggregation properties of activated platelets. For example, it is known that fibrinogen forms the bonds between platelets using activated integrin IIbIIIa. Although fibrinogen does not interact with plasminogen in plasma, there is a suggestion that Lys-plasminogen may bind fibrinogen, immobilized on the platelet membrane and impede the formation of platelet aggregates. Thrombospondin is secreted from the activated platelets and remains bound to the platelet membrane due to the presence of its specific receptor CD47. Thrombospondin is known for its ability to bind plasminogen. It was recently demonstrated that it is an important component, influencing the efficiency of collagen- and thrombin-induced adhesion of washed platelets [17]. There is a suggestion, that thrombospondin promotes platelet aggregation and fibrinogen binding due to the integrin IIbIIIa activation. And, finally, we can't exclude a possible role of vitronectin in the observed effect of Lys-plasminogen. Contrary to vitronectin of plasma, vitronectin of platelets, secreted during the activation, is a required component for efficient aggregation. The animals with vitronectin-deficient platelets did not have the second aggregation wave [18]. The structure of vitronectin contains the sites, responsible for binding to plasminogen. It is probable that the blocking of these sites by exogenous Lys-plasminogen inhibits the platelet aggregation.

However, in spite of all these speculations, the precise mechanism of the inhibitory effect of Lys- plasminogen may be elucidated only after further additional investigations.

Conclusions. It was first determined that Lys- plasminogen has the inhibitory effect on the aggregation of washed platelets, stimulated by thrombin and collagen.

The absence of the proenzyme influence on ristocetin-induced aggregation indicates that Lys-plasminogen does not affect the aggregation through GP Ib/IX.

We established a dose-dependent manner of the inhibitory effect of Lys-plasminogen on the platelet aggregation. The most significant effect is observed at the concentration of Lys-plasminogen of $1.2 \mu \mathrm{M}$.

Glu-plasminogen and plasmin do not influence the platelet aggregation under experiment conditions.

The inhibition of platelet aggregation by Lys-plasminogen in the presence of aprotinin makes it impossible for plasmin to participate in the realization of the inhibitory effect of zymogene.

\section{Я. М. Рока-Мойя, Д. Д. Жерносєков, Т. В. Гриненко}

Вплив плазміногену/плазміну на агрегаційну

здатність тромбоцитів

Інститут біохімії ім. О. В. Палладіна НАН України

Вул. Леонтовича, 9, Київ, Україна, 0160

Резюме

Мета. Визначити вплив Глу- $і$ Ліз-форм плазміногену та плазміну на агрегаиію тромбочитів, індуковану різними агоністами. Методи. Агрегатометрія. Спектрофотометрія. Результати. Отримано дані щодо інгібувального впливу Ліз-плазміногену на агрегаиію відмитих тромбочитів людини. Дію проферменту спостерігали на другій хвилі агрегаиї̈ тромбоцитів. Показано дозозалежний характер його інгібувального ефекту на агрегацію тромбоцитів, стимульованих тромбіном. Ристоміцин-індукована агре-гація не пригнічується Ліз-плазміногеном. Глу-плазміноген і плазмін не впливають на функиіональні властивості клітин за умов експерименту. Інгібітор серинових протеїназ апротинін не впливає на ефект інгібування агрегаиії Ліз-плазміногеном. Висновки. Вперше встановлено інгібувальний вплив Ліз-плазміногену на агрегаиію тромбоцитів, стимульованих тромбіном $і$ колагеном. Відсутність дії проферменту на агрегащію, індуковану ристоміиином, вказує на те, шо Ліз-плазміноген не впливає на ланку агрега- иї̈, яка реалізується за участі ГП Ib/IX. Інгібування Ліз-плазміногеном агрегаиї тромбоцитів за присутності апротиніну робить неможливою участь плазміну в реалізаиії інгібувального ефекту зимогену. 
Ключові слова: агрегачія відмитих тромбочитів, плазміноген, плазмін.

\section{Я. М. Рока-Мойя, Д. Д. Жерносеков, Т. В. Гриненко}

Влияние плазминогена/плазмина на агрегационные свойства тромбоцитов

\section{Резюме}

Цель. Изучить влияние Глу-, Лиз-форм плазминогена и плазмина на агрегацию тромбоцитов, индуцируемую различными агонистами. Методы. Агрегатометрия. Спектрофотометрия. Резульmambl. Получены данные об ингибирующем влиянии Лиз-плазминогена на агрегацию отмытых тромбоцитов человека. Действие профермента проявлялось во время второй волны агрегации. Показан дозозависимый характер его ингибирования агрегации тромбоцитов, стимулированных тромбином. Ристомицин-индуциированная агрегация не подавляется Лиз-плазминогеном. Глуплазминоген и плазмин не влияют на функциональные свойства клеток в условиях эксперимента. Ингибитор сериновых протеиназ апротинин не изменяет характера ингибирования агрегации Лиз-плазминогеном. Выводы. Впервые установлен ингибирующий эффект Лиз-плазминогена на агрегацию тромбочитов, стимулированных тромбином и коллагеном. Отсутствие влияния профермента на ристомицин-индуцированную агрегацию указывает на то, что Лиз-плазминоген не действует на путь агрегации, реализуемый при участии ГПІЬ/ІХ. Ингибирование Лиз-плазминогеном агрегаиии тромбоичтов в присутствии апротинина исключает участие плазмина в реализации ингибирующего эффекта.

Ключевые слова: агрегация отмытых тромбоцитов, плазминоген, плазмин.

\section{REFERENCES}

1. Irigoyen J. P., Munoz-Canoves P., Montero L., Koziczak M., Nagamine $Y$. The plasminogen activator system: biology and regulation // Cell Mol. Life Sci.-1999.-56, N 1-2.-P. 104-132.

2. Herren T., Swaisgood C. M., Plow E. F. Regulation of plasminogen receptors // Front Biosci.-2003.-8.-d. 1-8.

3. Miles L. A., Plow E. F. Binding and activation of plasminogen on the platelet surface // J. Biol. Chem.-1985.-260, N 7.P. 4303-4311.

4. Miles L. A., Hawley S. B., Baik N., Andronicos N. M., Castellino F. J., Parmer R. J. Plasminogen receptors: the sine qua non of cell surface plasminogen activation // Front. Biosci.-2005.10.-P. 1754-1762.

5. Miles L. A., Dahlberg C. M., Plow E. F. The cell-binding domains of plasminogen and their function in plasma // J. Biol. Chem.-1988.-263, N 24.-P. 11928-11934.

6. Niewiarowski S., Senyi A. F., Gillies P. Plasmin-induced platelet aggregation and platelet release reaction // J.Clin. Invest.1973.-52, N 7.-P. 1647-1659.
7. Schafer A. I., Maas A. K., Ware J. A., Johnson P. C., Rittenhouse S. E., Salzman E. W. Platelet protein phosphorylation, evaluation of cytosolic calcium, and inositol phospholipid breakdown in platelet activation induced by plasmin // J. Clin. Invest.1986.-78, N 1.-P. 73-79.

8. Torr S. R., Winters K. J., Santoro S. A., Sobel B. E. The nature of interaction between tissue-type plasminogen activator and platelets // Thromb. Res.-1990.-59, N 2.-P. 279-293.

9. Fry E. T. A., Grace A. M., Sobel B. E. Interactions between pharmacologic concentrations of plasminogen activators and platelets // Fibrinolysis.-1989.-3, N 3.-P. 127-136.

10. Winters K. J., Eisenberg P. R., Jaffe A. S., Santoro S. A. Dependence of plasmin-mediated degradation of platelet adhesive receptors in temperature and $\mathrm{Ca}^{2+} / /$ Blood.-1990.-76, $\mathrm{N}$ 8.P. 1546-1557.

11. Roka-Moya Y. M., Zhernossekov D. D., Zolotareva E. M., Grinenko $T$. $V$. The influence of exogenous Lys-plasminogen on ADP-induced platelet aggregation // Bulletin of the University of Kiev, series: Biology.-2011.-58.-P. 34-36.

12. Gear A. R., Suttitanamongkol S., Viisoreanu D., PolanowskaGrabowska R. K., Raha S., Camerini D. Adenosine diphosphate strongly potentiates the ability of the chemokines MDC, TARC, and SDF-1 to stimulate platelet function // Blood.-2001.-97, N 4.-P. 937-945.

13. Zubovskaya E. T., Svetlitskaya S. G. Hemostasis system. Theoretical base and methods of investigation.-Minsk: BGUFK, 2010.-310 p.

14. Barkagan Z. S., Momot A. P. Diagnostics and controlled therapy of hemostasis abnormalities.-Moscow: Newdiamed, 2008.289 p.

15. Aisina R. B., Mukhametova L. I., Gulin D. A., Levashov M. Y., Prisyazhnaya N. V., Gershkovich K. B., Varfolomeyev S. D. Inhibitory effect of angiostatins on activity of the plasminogen/ plasmin activator system // Biochemistry (Moscow).-2001.-74, N 10.-P. 1104-1113.

16. Pasche B., Ouimet H., Francis S., Loscalzo J. Structural changes in platelet glycoprotein IIb/IIIa by plasmin: determinants and functional consequences // Blood.-1994.-83, N 2.-P. 404414.

17. Isenberg J. S., Romeo M. J., Yu C., Yu C. K., Nghiem K., Monsale J., Rick M. E., Wink D. A., Frazier W. A., Roberts D. D. Thrombospondin-1 stimulates platelet aggregation by blocking the antithrombotic activity of nitric oxide/cGMP signaling // Blood.2008.-111, N 2.-P. 613-623.

18. Reheman A., Gross P., Yang H., Chen P., Allen D., Leytin V., Free man J., Ni H. Vitronectin stabilizes thrombi and vessel occlusion but plays a dual role in platelet aggregation // J. Thromb. Haemost.-2005.-3, N 5.-P. 875-883.

Received 12.03.12 